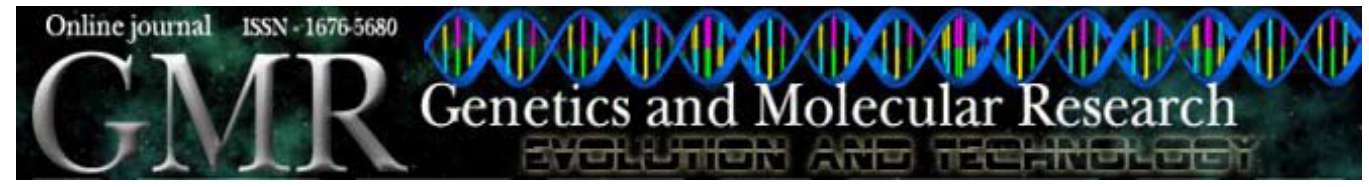

Short Communication

\title{
Development and characterization of microsatellite markers for the walking goby (Scartelaos viridis; Gobiidae)
}

\author{
D.Q. Sun, H.Y. Li, T.J. Xu and R.X. Wang \\ Key Laboratory for Marine Living Resources and Molecular Engineering, \\ College of Marine Science, Zhejiang Ocean University, Zhoushan, P.R. China \\ Corresponding author: R.X. Wang \\ E-mail: wangrixin1123@126.com
}

Genet. Mol. Res. 10 (1): 203-207 (2011)

Received September 27, 2010

Accepted November 16, 2010

Published February 8, 2010

DOI 10.4238/vol10-1gmr1015

\begin{abstract}
Scartelaos viridis (walking goby) is a small edible fish that inhabits warm inshore environments. To provide molecular information of S. viridis, we developed and characterized microsatellite markers for this species. Using (CA) ${ }_{15}$-enriched genomic libraries of Scartelaos viridis, 44 positive clones were sequenced; 34 sequences contained multiple repeat motifs (di-, tri- and tetra-nucleotide). In all, 23 primer pairs were designed and 15 were successfully amplified. Forty-two $S$. viridis individuals collected from the East China Sea were used to characterize the polymorphism at each locus. Three loci (13\%) were polymorphic, with three to six alleles. The observed and expected heterozygosity ranged from 0.1000 to 0.4500 and from 0.4487 to 0.7580 , respectively. The polymorphism information content per locus ranged from 0.4214 to 0.7510 . Three loci significantly deviated from the Hardy-Weinberg equilibrium (adjusted P value $=0.017$ ); the pairwise tests for linkage disequilibrium between Scvi-1-13 and Scvi-211 were significant $(\mathrm{P}<0.05$, adjusted $\mathrm{P}$ value $=0.017)$. The low number of polymorphic microsatellite loci may be due to the close genetic relationship of the individuals that we collected and the large size of the motifs.
\end{abstract}

Key words: Scartelaos viridis; Microsatellite; Molecular marker 


\section{INTRODUCTION}

Microsatellites, also known as simple sequence repeats (SSRs), are regions of DNA that exhibit short repetitive sequence motifs. These motifs are often composed of 1-6 bp repeats and high polymorphism occurs for different repeats. As microsatellites have some unique characteristics, such as co-dominance of alleles, high allelic diversity, and the relatively simple polymerase chain reaction (PCR)-based screening methods that are reproducible, they have been widely employed in recent years in population genetic studies of numerous species and such application is continuously expanding (Sekino and Hara, 2001; Kohlmann et al., 2005; Mia et al., 2005; Selkoe and Toonen, 2006; Liu et al., 2009). At the same time, microsatellites have been successfully used in genetic mapping and genome analysis (Chen et al., 1997; Li et al., 2000), genotype identification, variety protection seed purity evaluation (Senior et al., 1998), germplasm conservation (Brown et al., 1996), and marker assisted breeding (Weising et al., 1997).

As the microsatellite marker technique is based on specific amplification, the genome DNA of species or a part of the sequence containing microsatellite DNA sequence should be obtained first. Primers are then designed for PCR amplification. At present, microsatellite sequences have been isolated mainly in the following ways: genomic sequencing, and enrichment of the microsatellite separation method. The latter method is widely employed because of its high efficiency of isolation and time savings (Kandpal et al., 1994; Brown et al., 1995).

Scartelaos viridis (walking goby) is a species of small fish that inhabits warm inshore environments around the oceans of China. In recent decades, the walking goby has become popular in some cities in the south of China for its taste and nutrition. The objectives of this study were to design microsatellite primers based on amplified fragment length polymorphism (AFLP) of sequences containing repeats (FIASCO) method (Zane et al., 2002), and to develop and analyze the genetic characterization of microsatellite loci for $S$. viridis.

\section{MATERIAL AND METHODS}

\section{DNA extraction and enrichment for microsatellites}

Forty-two $S$. viridis individuals were collected from the Zhoushan fishing ground of the East Sea $\left(30^{\circ} \mathrm{N}, 122^{\circ} \mathrm{E}\right)$. Total genomic DNA was isolated from the fin clips using the standard phenol-chloroform method with some modification, which was subsequently dissolved in $100 \mu \mathrm{L}$ TE buffer and then was determined on a $1 \%$ agarose gel stained with ethidium bromide using known molecular weight standards. DNA was stored at $-20^{\circ} \mathrm{C}$. An enriched partial genomic library for the repeat motif $(\mathrm{CA})_{15}$ was constructed essentially using a DNA pool from two individuals and following the modified FIASCO protocol.

Total genomic DNA pool was simultaneously digested with the MseI restriction enzyme (MBI). DNA fragments ranging from 250 to $1000 \mathrm{bp}$ were isolated from a $1.5 \%$ agarose gel and purified using the QIAquick Gel Extraction Kit (Qiagen). These fragments were ligated to MseI AFLP adapters OligoA (5'-TAC TCA GGA CTC AT-3') and OligoB (5'-GAC GAT GAG TCC TGA G-3') and then amplified by PCR using adaptor-specific primers (MseI-N: 5'-GATGAGTCCTGAGTAAN-3'). PCR conditions were: 1X Taq DNA polymerase buffer, 1.0-1.5 mM MgCl 2,120 ng primer MseI-N, $200 \mu \mathrm{M}$ each dNTPs, $1.0 \mathrm{U}$ 
Taq DNA polymerase (Tiangen) and $5 \mu \mathrm{L}$ of a 1/10 dilution of digested-ligation DNA. PCR was performed in a volume of $25 \mu \mathrm{L}$ following the program: $94^{\circ} \mathrm{C}$ for $5 \mathrm{~min} ; 30$ cycles at $94^{\circ} \mathrm{C}$ for $30 \mathrm{~s}, 53^{\circ} \mathrm{C}$ for $30 \mathrm{~s}$, and $72^{\circ} \mathrm{C}$ for $50 \mathrm{~s} ; 72^{\circ} \mathrm{C}$ for $5 \mathrm{~min}$ for final extension. DNA fragments between 300-1000 bp were isolated and purified.

Genomic DNA fragments containing SSRs were captured by hybridization to (CA) ${ }_{15}$ biotin-labeled probes. For enrichment, the adaptor-ligated DNA fragments were denatured at $95^{\circ} \mathrm{C}$ for $8 \mathrm{~min}$, and then hybridized to biotin-labeled probes in $70 \mu \mathrm{L}$ hybridization solution at $65^{\circ} \mathrm{C}$ for half an hour. The DNA hybridized to the probe was separated and captured by streptavidin magnetic beads at room temperature for half an hour. The microsatellites were obtained following nonspecific and specific washing. Amplifying the microsatellite DNA using the same procedure as the former PCR, the products were ligated to pGEM-T vectors (Promega) according to manufacturer instructions and then cloned to TOP10 cells following the standard protocol.

\section{Primer design and PCR amplification}

Some of the positive clones, which were screened via PCR with T7/SP6 and (CA) primers, were sequenced by T7 primer on an ABI 3730 automated sequencer. Primers were designed in the flanking regions of the repeat motifs (repeating size $\geq 12 \mathrm{bp}$ ) using the PRIMER PREMIER 5.0 software. As some factors will affect the specificity of the amplification, the optimal conditions for PCR amplifications for each primer should be determined by adjusting the annealing temperature and/or $\mathrm{Mg}^{2+}$ concentration. Then, polymorphism at each locus was determined using 42 individuals. PCR amplifications were carried out in $25-\mu \mathrm{L}$ volumes containing $2.5 \mu \mathrm{L} 10 \mathrm{X}$ PCR buffer, $1.5 \mathrm{mM} \mathrm{MgCl}_{2}, 0.2 \mathrm{mM}$ dNTPs, $0.2 \mu \mathrm{M}$ of the forward and reverse primers, and 1.5 units Taq polymerase (Tiangen). Cycling conditions were $94^{\circ} \mathrm{C}$ for 4 min followed by 30 cycles at $94^{\circ} \mathrm{C}$ for $40 \mathrm{~s}$, annealing temperature for $30 \mathrm{~s}$, and $72^{\circ} \mathrm{C}$ for $40 \mathrm{~s}$, followed by 1 cycle of $72^{\circ} \mathrm{C}$ for $5 \mathrm{~min}$ and then holding at $4^{\circ} \mathrm{C}$. PCR amplification was performed on an ABI 9700 thermal cycler.

The products of PCR amplifications were determined on 1.5\% agarose gel and then were denatured at $96^{\circ} \mathrm{C}$ for $8 \mathrm{~min}$ using denaturant ( $98 \%$ formamide, $10 \mathrm{mM} \mathrm{0.25 \%}$ EDTA, $0.25 \%$ FF). The denatured amplified products were separated on $6 \%$ denaturing polyacrylamide (19:1 acrylamide:bis-acrylamide) gels using silver staining. A denatured pBR322 DNA/MspI molecular weight marker (Tiangen) was used as a size standard to identify alleles (Xu et al., 2009).

\section{Data analysis}

The number of alleles, and observed $\left(H_{\mathrm{O}}\right)$ and expected $\left(H_{\mathrm{E}}\right)$ heterozygosity were estimated using the POPGENE32 software (Yeh and Boyle, 1997), and the ARLEQUIN 3.11 software (Schneider et al., 2000) was used to calculate Hardy-Weinberg equilibrium (HWE) expectations and genotypic linkage disequilibrium. All results for multiple tests were corrected using Bonferroni's correction (Rice, 1989).

\section{RESULTS AND DISCUSSION}

From the (CA) $)_{15}$-enriched genomic libraries, 44 clones were sequenced successfully and $34(77.3 \%)$ sequences contained sufficient repeat motifs (di-, tri- and tetra-nucleotide). The motif repeats ranged from 3 to 33, and only those repeating more than five times were 
regarded as microsatellites. In all, 23 primer pairs were designed as the remaining sequences and were too close to the cloning site to design primers.

Details of the newly developed microsatellite loci are listed in Table 1. Fifteen of the 23 primers were successfully amplified and 3 loci were shown to be polymorphic in $S$. viridis. The variability measures across 42 individuals of walking goby are also summarized in Table 1. Of the 15 pairs amplified primers, 3 polymorphic loci (Scvi-1-13, Scvi-2-11 and Scvi-2-24) showed 3-6 alleles. $\mathrm{H}_{\mathrm{O}}$ and $\mathrm{H}_{\mathrm{E}}$ ranged from 0.1000 to 0.4500 and from 0.4487 to 0.7580 , respectively. The polymorphism information content (PIC) per locus ranged from 0.4214 to 0.7510 , of which Scvi-1-13 was middle polymorphic $(0.25<$ PIC $<0.5)$, while the other two loci were highly polymorphic (PIC $>0.5)$. HWE probability tests showed all three loci significantly deviated from $\operatorname{HWE}(\mathrm{P}<0.05$, adjusted $\mathrm{P}=0.017)$. And strong deviations from $\mathrm{HWE}(\mathrm{P}<0.001$, adjusted $\mathrm{P}=0.0003$ ) were observed in Scvi-1-13, possibly due to the presence of null alleles. According to the pairwise tests for linkage disequilibrium, only one pairwise test (Scvi-1-13 and Scvi-2-11) was significant $(\mathrm{P}<0.05$, adjusted $\mathrm{P}=0.017)$.

\begin{tabular}{|c|c|c|c|c|c|c|c|c|c|c|}
\hline Locus & Motif & Type* & Primer sequence $\left(5^{\prime}-3^{\prime}\right)$ & $\begin{array}{l}\text { Size } \\
\text { (bp) }\end{array}$ & $\begin{array}{l}\mathrm{Tm} \\
\left({ }^{\circ} \mathrm{C}\right) \\
\end{array}$ & $\begin{array}{l}\mathrm{Mg}^{2+} \\
(\mathrm{mM})\end{array}$ & $\mathrm{N}_{\mathrm{A}}$ & $H_{\mathrm{O}} H_{\mathrm{E}}$ & PIC & $\begin{array}{l}\text { Accession } \\
\text { No. }\end{array}$ \\
\hline Scvi-1-8 & $(\mathrm{AG})_{12}(\mathrm{TG})_{8}$ & $\mathrm{C}$ & $\begin{array}{l}\text { CGGCCGCGGGAATTCGAT } \\
\text { TGACCCTGGCCCTGCACA }\end{array}$ & 197 & 56 & 1.5 & 1 & & & HQ128584 \\
\hline Scvi-1-10 & $\begin{array}{c}\left(\mathrm{CGTG}(\mathrm{TG})_{4}\right)_{2} \\
(\mathrm{CGTG})_{4}\end{array}$ & $\mathrm{C}$ & $\begin{array}{l}\text { ATGAAGCAACGGACCCTC } \\
\text { AGCGCTACGTCAAACTGATA }\end{array}$ & 241 & 54 & 1.5 & 1 & & & HQ128585 \\
\hline Scvi-1-13 & $(\mathrm{GAG})_{5}$ & $P$ & $\begin{array}{l}\text { GTCTGGGCTGTATCTCATT } \\
\text { CTAGCGTCATAAACACCAA }\end{array}$ & $144-156$ & 50 & 1.5 & 4 & $\begin{array}{l}0.1000 \\
0.4487^{* *}\end{array}$ & 0.4214 & HQ128586 \\
\hline Scvi-2-4 & $(\mathrm{GA})_{6}$ & $P$ & $\begin{array}{l}\text { TCTCATACAGTGCCAGTT } \\
\text { TCACTACTCTGCAAATACAC }\end{array}$ & 128 & 48 & 1.5 & 1 & & & HQ128587 \\
\hline Scvi-2-10 & $\left(\mathrm{GAC}(\mathrm{AG})_{4}\right)_{5}$ & $\mathrm{C}$ & $\begin{array}{l}\text { ACGAACATTTAAGACCAG } \\
\text { TTCCAAACAGGAAGTGAT }\end{array}$ & 188 & 50 & 1.5 & 1 & & & HQ128588 \\
\hline Scvi-2-11 & (TC) ${ }_{9}$ & $P$ & $\begin{array}{l}\text { CACCCACCTGTTGGTACTATTT } \\
\text { TCAAACGCACTCCGATGA }\end{array}$ & $244-254$ & 52 & 1.5 & 6 & $\begin{array}{l}0.4500 \\
0.7580^{* *}\end{array}$ & 0.7510 & HQ128589 \\
\hline Scvi-2-12 & $(\mathrm{AG})_{18}(\mathrm{TG})_{24}$ & $\mathrm{C}$ & $\begin{array}{l}\text { CAACGGACTCAGGAAAGG } \\
\text { TGTCACGAGGACGCAGAA }\end{array}$ & 216 & 52 & 1.5 & 1 & & & HQ128590 \\
\hline Scvi-2-20 & $\begin{array}{l}(\mathrm{TG})_{10} \\
\text { TACG(TG) })_{8}\end{array}$ & I & $\begin{array}{l}\text { GCTACAAGGCTCTACAGG } \\
\text { GCTAGTTTGACATGACCC }\end{array}$ & 131 & 43 & 1.5 & 1 & & & HQ128591 \\
\hline Scvi-2-24 & $(\mathrm{TG})_{19}$ & $\mathrm{P}$ & $\begin{array}{l}\text { GGATTCACAGGAAAAGGA } \\
\text { CAAACCAGAAGAAGACCC }\end{array}$ & $262-266$ & 54 & 1.5 & 3 & $\begin{array}{l}0.2778 \\
0.6373^{* *}\end{array}$ & 0.5602 & HQ128592 \\
\hline Scvi-3-17 & $(\mathrm{TG})_{15}(\mathrm{TGG})_{3}$ & $\mathrm{C}$ & $\begin{array}{l}\text { CCATCTCCTCCCTGTGGCT } \\
\text { ACCGTAGAGGGCGCTGTTG }\end{array}$ & 245 & 45 & 1.5 & 1 & & & HQ128593 \\
\hline Scvi-3-19 & $(\mathrm{TG})_{33}$ & $\mathrm{P}$ & $\begin{array}{l}\text { AACAGAAAGCTGAAACCCAT } \\
\text { ATCTTGCAGGCCCAATCC }\end{array}$ & 155 & 52 & 1.5 & 1 & & & HQ128594 \\
\hline Scvi-4-10 & $(\mathrm{AG})_{23}(\mathrm{TG})_{26}$ & $\mathrm{C}$ & $\begin{array}{l}\text { AACAATGAAGCAACGGAC } \\
\text { AGCGCTACATCAAACTGA }\end{array}$ & 211 & 50 & 1.5 & 1 & & & HQ128595 \\
\hline Scvi-4-17 & $(A G)_{8}$ & $\mathrm{P}$ & $\begin{array}{l}\text { GAGATTGGCGCAAAACAA } \\
\text { CCCATGTTCCCCTTTCTA }\end{array}$ & 150 & 54 & 1.0 & 1 & & & HQ128596 \\
\hline Scvi-4-18 & $(\mathrm{TG})_{29}$ & $\mathrm{P}$ & $\begin{array}{l}\text { AGGAAAGGATAGAAGAGTC } \\
\text { CTGAGCTTGGCTACTAAA }\end{array}$ & 167 & 43 & 1.5 & 1 & & & HQ128597 \\
\hline Scvi-4-20 & $(\mathrm{AG})_{6}$ & $\mathrm{P}$ & $\begin{array}{l}\text { ATTGGGACAAAACAGGAG } \\
\text { TCTTTGTCCTTCTCACCC }\end{array}$ & 141 & 50 & 1.0 & 1 & & & HQ128598 \\
\hline
\end{tabular}

\footnotetext{
*The types $\mathrm{P}$, I and $\mathrm{C}$ stand for perfect, imperfect and compound, respectively. Tm = annealing temperature; $\mathrm{N}_{\mathrm{A}}$ $=$ number of alleles; $\mathrm{PIC}=$ polymorphism information content; $H_{\mathrm{O}}=$ observed heterozygosity and $H_{\mathrm{E}}=$ expected heterozygosity. ${ }^{*}$ Denotes significant deviation from HWE after Bonferroni's correction $(\mathrm{P}<0.016)$.
}

Although the number of sequences surveyed in this study was limited, our results still certainly suggest that the $S$. viridis genome has an abundance of microsatellites (77.3\%), but the polymorphism of these loci was low, since only $13 \%$ of the loci showed polymorphism. 
Maybe the individuals used in this study are too closely related, affecting the test for polymorphism. Besides, the polymorphism per locus is positively related to the motifs repeat size (Weber, 1990; Brandström and Ellegren, 2008). Some microsatellites found in $S$. viridis repeated more than 20 times, which may be too large, limiting the mutation rates.

\section{ACKNOWLEDGMENTS}

Research supported by Open Foundation from Ocean Fishery Science and Technology in the Most Important Subjects of Zhejiang (\#20100209) and Seeding Grants from Programs of Science and Technology Commission Foundation of Zhejiang Province.

\section{REFERENCES}

Brandström M and Ellegren H (2008). Genome-wide analysis of microsatellite polymorphism in chicken circumventing the ascertainment bias. Gen. Res. 18: 881-887.

Brown J, Hardwick LJ and Wright AF (1995). A simple method for rapid isolation of microsatellites from yeast artificial chromosomes. Mol. Cell Probes 9: 53-57.

Brown SM, Hopkins MS, Mitchell SE, Senior ML, et al. (1996). Multiple methods for the identification of polymorphic simple sequence repeats (SSRs) in sorghum [Sorghum bicolor (L.) Moench]. Theor. Appl. Genet. 93: 190-198.

Chen X, Temnykh S, Xu Y, Cho YG, et al. (1997). Development of a microsatellite framework map providing genome wide coverage in rice (Oryza sativa L.). Theor. Appl. Genet. 95: 553-567.

Kandpal RP, Kandpal G and Weissman SM (1994). Construction of libraries enriched for sequence repeats and jumping clones, and hybridization selection for region-specific markers. Proc. Natl. Acad. Sci. U. S. A. 91: 88-92.

Kohlmann K, Kersten P and FlajÍhans M (2005). Microsatellite based genetic variability and differentiation of domesticated, wild and feral common carp (Cyprinus carpio L.) populations. Aquaculture 247: 253-266.

Li CD, Rossnagel BG and Scoles GJ (2000). The development of oat microsatellite markers and their use in identifying Avena species and oat cultivars. Theor. Appl. Genet. 101: 1259-1268.

Liu JY, Lun ZR, Zhang JB and Yang TB (2009). Population genetic structure of striped mullet, Mugil cephalus, along the coast of China, inferred by AFLP finger printing. Biochem. Syst. Ecol. 37: 266-274.

Mia MY, Taggart JB, Gilmour AE, Gheyas AA, et al. (2005). Detection of hybridization between Chinese carp species (Hypophthalmichthys molitrix and Aristichthys nobilis) in hatchery broodstock in Bangladesh, using DNA microsatellite loci. Aquaculture 247: 267-273.

Rice WE (1989). Analyzing tables of statistical tests. Evolution 43: 223-225.

Schneider S, Roessli D and Excoffier L (2000). ARLEQUIN: a software for population genetics data analysis. Version 2.0. Genetics and Biometry Laboratory, Department of Anthropology, University of Geneva, Switzerland.

Sekino M and Hara M (2001). Application of microsatellite markers to population genetics studies of Japanese flounder Paralichthys olivaceus. Mar. Biotechnol. 3: 572-589.

Selkoe KA and Toonen RJ (2006). Microsatellites for ecologists: a practical guide to using and evaluating microsatellite markers. Ecol. Lett. 9: 615-629.

Senior ML, Murphy JP, Goodman MM and Stuber CW (1998). Utility of SSRs for determining genetic similarities and relationships in maize using an agarose system. Crop Sci. 38: 1088-1098.

Weber JL (1990). Informativeness of human (dC-dA)n.(dG-dT)n polymorphisms. Genomics 7: 524-530.

Weising K, Winter P, Huttel B and Kahl G (1997). Microsatellite markers for molecular breeding. J. Crop Prod. 1: 113-143.

$\mathrm{Xu}$ TJ, Shao CW, Liao XL and Chen SL (2009). Isolation and characterization of polymorphic microsatellite DNA markers in the rock bream (Oplegnathus fasciatus). Conserv. Genet. 10: 527-529.

Yeh FC and Boyle TJB (1997). Population genetic analysis of co-dominant and dominant markers and quantitative traits. Belg. J. Bot. 129: 157.

Zane L, Bargelloni L and Patarnello T (2002). Strategies for microsatellite isolation: a review. Mol. Ecol. 11: 1-16. 